\title{
Comparative Antioxidant Capacity and Enzyme Inhibitory Effect of Extracts from Prunus avium Leaves
}

\author{
Sengul UYSAL 으 \\ Erciyes University Halil Bayraktar Health Services Vocational College, Kayseri, TURKEY \\ Erciyes University, Drug Application and Research Center, Kayseri, TURKEY \\ Corresponding Author: senguluysal@erciyes.edu.tr
}

Received Date: 14.01 .2020

Accepted Date: 22.10 .2020

\begin{abstract}
Aim of study: This study aimed to investigate the antioxidant capacity and enzyme inhibitory effect of different solvent extracts obtained from Prunus avium leaves.

Material and methods: The antioxidant capacity were evaluated using in vitro assays including DPPH, ABTS, CUPRAC, FRAP, phosphomolybdenum and metal chelating activity. Enzyme inhibitory effects were screened against $\mathrm{AChE}, \mathrm{BChE}, \alpha$-amylase, $\alpha$-glucosidase and tyrosinase enzyme. Additionally, total phenolic and flavonoid content were determined spectrophotometrically.

Main results: The water extract yielded the highest phenolic content $(66.65 \mathrm{mgGAE} / \mathrm{g})$. In antioxidant assays, water extract exhibited strong antioxidant capacity (with exception of metal chelating activity). Methanol extract showed the highest enzyme inhibitory effect compared to other extracts.

Highlights: This study proved that $P$. avium leaves have the potential for the development of new phytopharmaceuticals or food additives.

Keywords: Prunus avium, Antioxidant, Enzyme Inhibition

Prunus avium Yapraklarından Elde Edilen Ekstraktların

Karşılaştırılmalı Antioksidan Kapasitesi ve Enzim Inhibisyon

Etkisi
\end{abstract}

Öz

Çalışmanın amact: $\mathrm{Bu}$ çalışmanın amacı Prunus avium yapraklarından elde edilen farklı çözücü ekstraktlarının antioksidan kapasitesini ve enzim inhibitör aktivitesini araştırmaktır.

Materyal ve yöntem: Antioksidan kapasite DPPH, ABTS, CUPRAC, FRAP, fosfomolibdat ve metal şelatlamayı içeren in vitro deneylerle değerlendirildi. Enzim inhibitor ektisi AChE, BChE, $\alpha$-amilaz, $\alpha$ glukozidaz ve tirozinaz enzimlerine karşı tarandı. Ek olarak, total fenolik ve flavonoid içerik spektrofotometrik olarak belirlendi.

Temel sonuçlar: Su ekstraktı en yüksek fenolik içeriğe sahiptir (66.65 mgGAE/g). Antioksidan deneylerde, su ekstraktı güçlü antioksidan kapasitesi sergiledi (metal şelatlama aktivitesi istisna olarak). Metanol ekstraktı diğer ekstraktlarla karşılaştırıldığında en yüksek enzim inhibitor etki gösterdi.

Araştırma vurguları: Bu çalışma $P$. avium yapraklarının yeni fitofarmasötikler veya gıda katkı maddelerinin geliştirme potansiyeline sahip olduğunu kanttladı

Anahtar kelimeler: Prunus avium, Antioksidan, Enzim İnhibisyonu

\section{Introduction}

Prunus avium L. is an economically important fruit tree of the family Rosaceae. $P$. avium fruits are much appreciated worldwide because of their richness in bioactive compounds (Nawirska-Olszańska et al., 2017). Turkey is the leading sweet cherry producer (Średnicka-Tober et al., 2019). Previous phytochemical researches on $P$. avium showed the presence of polyphenols, vitamins, anthocyanins, and carotenoids (Gonçalves et al., 2004; Usenik et al., 2008; Serradilla et al., 2012). Furthermore, cherry consumption is associated with the prevention of several diseases such as diabetes, inflammatory, and Alzheimer's diseases (McCune et al., 2010; Wu et al., 2014; Kent et al., 2016).

Recently, many of the drug discovery approaches have been based on enzyme 
inhibition theory (Rauf \& Jehan, 2017). Inhibition of cholinesterase enzymes (AChE and $\mathrm{BChE}$ ) is a significant therapeutic target for the treatment of Alzheimer's disease (AD) (Masondo et al., 2019). $\alpha$-Amylase and $\alpha$-glucosidase enzymes play an important role in carbohydrate digestion. These enzymes are a promising strategy for treating type-2 diabetes (Rauf \& Jehan, 2017). Tyrosinase is a key enzyme in melanogenesis. Abnormal expression of tyrosinase is responsible for several skin diseases. Therefore, tyrosinase inhibitors have received great attention in cosmetic and medical applications (Chai et al., 2018). Commercially available inhibitors exhibited significant side effects; in this context, plants and by-products have played an important role in the research for new inhibitors.

Recent research is focused on the use of wastes and by-products originated from agricultural and food processing (Banerjee et al., 2017). Additionally, several investigators showed that not only fruit but also leaves of $P$. avium are characterized by high level of bioactive contents and antioxidant properties (Dziadek et al., 2018; Dziadek et al., 2019). According to the literature, there is a dearth of information available on the chemical constituents and biological properties of $P$. avium leaves.

Therefore, the aim of this present paper was assessed to antioxidant and enzyme inhibitory effect of $P$. avium leaves. To the best of our knowledge, this is the first study on enzyme inhibitory effect of leaves extracts obtained from $P$. avium.

\section{Material and Methods \\ Plant Material}

The leaves of Prunus avium L. were collected from Selcuk University, Alaaddin Keykubad Campus, Konya, Turkey in 2018 (1186 m, 38 01' 50", 32 30' 29"). The plant identification was authenticated by Dr. Evren Yildiztugay (Selcuk University). The leaves were dried at room temperature. Then, the dried leaves were ground to a fine powder using a laboratory mill.

\section{Preparation of Extracts}

The dried materials $(5 \mathrm{~g})$ were macerated with $100 \mathrm{~mL}$ of methanol, $50 \%$ methanol, and water at room temperature for $24 \mathrm{~h}$. Obtained extracts were filtered and stored in a refrigerator until further analysis.

\section{Total Bioactive Compounds}

The total phenolic (TPC) and flavonoids content (TFC) were evaluated by FolinCiocalteu and $\mathrm{AlCl}_{3}$ methods, respectively. All procedures are described in our papers (Uysal et al., 2017; Uysal et al., 2019; Zengin et al., 2019). Results were expressed as gallic acid and rutin equivalents for TPC and TFC, respectively.

\section{In Vitro Antioxidant Assays}

Antioxidant capacity (DPPH, ABTS, CUPRAC, FRAP, phosphomolybdenum, and metal chelating) were assessed using the methods previously described (Bahadori et al., 2018; Mollica et al., 2018; Grochowski et al., 2019).

\section{In Vitro Enzyme Inhibitory Assays}

The ability of the extracts obtained from $P$. avium leaves to inhibit the activity of acetylcholinesterase, butyrylcholinesterase, $\alpha$-amylase, $\alpha$-glucosidase, and tyrosinase was tested according to the procedures described previously (Uysal \& Aktumsek, 2015; Asghari et al., 2019; Mollica et al., 2019).

Statistical Analysis

Firstly, principal component (PCA) analysis was applied to visualize the similarity among the samples derived from three different polar solvents. Then, Oneway ANOVA and Tukey'test, with a confidence level of $95 \%$, were done to characterize the samples. All statistical analysis was performed using $\mathrm{R}$ software $\mathrm{v}$. 3.6.1.

\section{Results and Discussion}

The study of herbal medicines starts with the extraction procedures, which remains a crucial step in the separation of bioactive compounds of interest from plant matrix. For this purpose several methods and solvents are commonly used at the little research setting level, with the aim to increase the yield and quality of extraction at lower cost. In this study, the method of extraction employed was maceration, which is one of the most 
commonly used methods in medicinal plants research.

Maceration comprises of soaking plant stock in closed vessel with a solvent at room temperature and shaken frequently, for a required period of time. This technique is easy, simple and, has the ability to weaken and disrupt plant's cell wall, thereby enhancing and facilitating release of soluble bioactive compounds. Nevertheless, in this method choice of solvent used in the soaking process needs meticulous assessment (Azwanida, 2015).

Table 1. Total bioactive compounds of Prunus avium leaves

\begin{tabular}{lll}
\hline Samples & $\begin{array}{l}\text { Total phenolic content } \\
\text { (mg GAE/g extract) }\end{array}$ & $\begin{array}{l}\text { Total flavonoid content } \\
\text { (mg RE/g extract) }\end{array}$ \\
\hline Prunus avium-MeOH & $41.07 \pm 0.22^{* b}$ & $35.44 \pm 0.35^{\mathrm{a}}$ \\
\hline Prunus avium-50\% MeOH & $33.57 \pm 0.59^{\mathrm{c}}$ & $16.97 \pm 0.29^{\mathrm{c}}$ \\
\hline Prunus avium-Water & $66.65 \pm 0.78^{\mathrm{a}}$ & $20.97 \pm 0.18^{\mathrm{b}}$ \\
\hline
\end{tabular}

${ }^{*}$ Values expressed are means \pm SD. GAE, gallic acid equivalents, RE, rutin equivalents. Different superscripts indicate significant differences in the extracts $(p<0.05)$.

Likewise, plant provide abundant bioactive constituents, different in their structures, what determines their solubility in solvents of differing polarity. Accordingly, in the process of chemical compounds extraction from Prunus avium, methanol, $50 \%$ methanol and water were used as extraction solvents. Prepared samples were characterized in terms of total bioactive compounds (phenolic and flavonoid), and several biological activities including, antioxidant assays (ABTS and DPPH radical scavenging, CUPRAC, FRAP, phosphomolybdenum, metal chelating ability) and inhibition of main enzyme involve in diabetes mellitus, Alzheimer and skin's disease management. The generated dataset was firstly submitted to exploratory multivariate analysis PCA. By this statistical method we sought to evaluate the likeness between samples from a multidimensional point of view.

Results were shown in Figure 1, illustrating the sample plot, a clear segregation between samples was obtained. Two principal component accounting for $99.7 \%$ of total bioactivities variance were obtained. Component 1 separated water extracts from the less two polar extracts (methanol and 50\% methanol) depending on the level of antioxidant activities (DPPH, ABTS, FRAP, CUPRAC), anti-tyrosinase, anti-acetylcholinesterase and anti-amylase potentialities. Component 2 discriminated methanol and $50 \%$ methanol by the level of ferrous chelating, anti-butyrylcholinesterase, phosphomolybdenum and anti-glucosidase activities. Moreover, it was noted that phenolic contents were positively correlated with all antioxidant activities test, but negatively linked with ferrous chelating test. Accordingly, it seems that the ferrous chelating activities can be ascribed to the presence of non-phenolic compounds in extracts. Flavonoids content was linked with anti-butyrylcholinesterase and antiglucosidase assays. The antioxidant properties of polyphenols are well studied (Scalbert et al., 2005).

The inferences from the exploratory multivariate analysis confirmed the need to use an adequate solvent for phytoconstituents extraction. In fact there is no universal extraction solvent and/or method, thus the choice of extraction method and/or solvent depend on multiple factors such as, the study species, the target compounds. Afterwards through univariate statistical analysis, a characterization of samples in keeping with their biological activities were done.

Bioactive compounds such as polyphenols are ubiquitously found in herbals and have attracted much attention due to their numerous biological activities potentiality (Murayyan et al., 2017). As a result, while evaluating potential biological activities of healing plants, taking into consideration the polyphenols content is important. Thereby, first of all, total bioactive compounds including total phenolic and total flavonoid 
content were evaluated by spectrophotometric assays. The total amounts of TPC in extract ranged from 33.57 to 66.65 $\mathrm{mg} \mathrm{GAE} / \mathrm{g}$ extract and in total flavonoid content (TFC) from 16.97 to $35.44 \mathrm{mg} \mathrm{RE} / \mathrm{g}$ extract (Table 1) The highest amounts of total phenolic content were determined in $P$. avium -water extract (66.65 mg GAE/g). On the other hand, $P$. avium $-50 \% \mathrm{MeOH}$ extract contained the lowest TPC $(33.57 \mathrm{mg}$ $\mathrm{GAE} / \mathrm{g})$. P. avium-MeOH extract had the highest TFC, followed by $P$. avium-water extract and $P$. avium-50\% $\mathrm{MeOH}$. Previous study (Dziadek et al., 2019) reported total polyphenols in leaves, petioles and fruit of sweet cherry. Similarly, total phenolic and flavonoid contents of three Spanish local varieties of $P$. avium were analysed by Acero et al. (2019) and significant differences in the content of TFC and TPC were found between cultivars. Furthermore, several authors have indicated correlation between antioxidant capacity and total bioactive compounds (TPC and TFC) ( $\mathrm{Li}$ et al., 2009). 


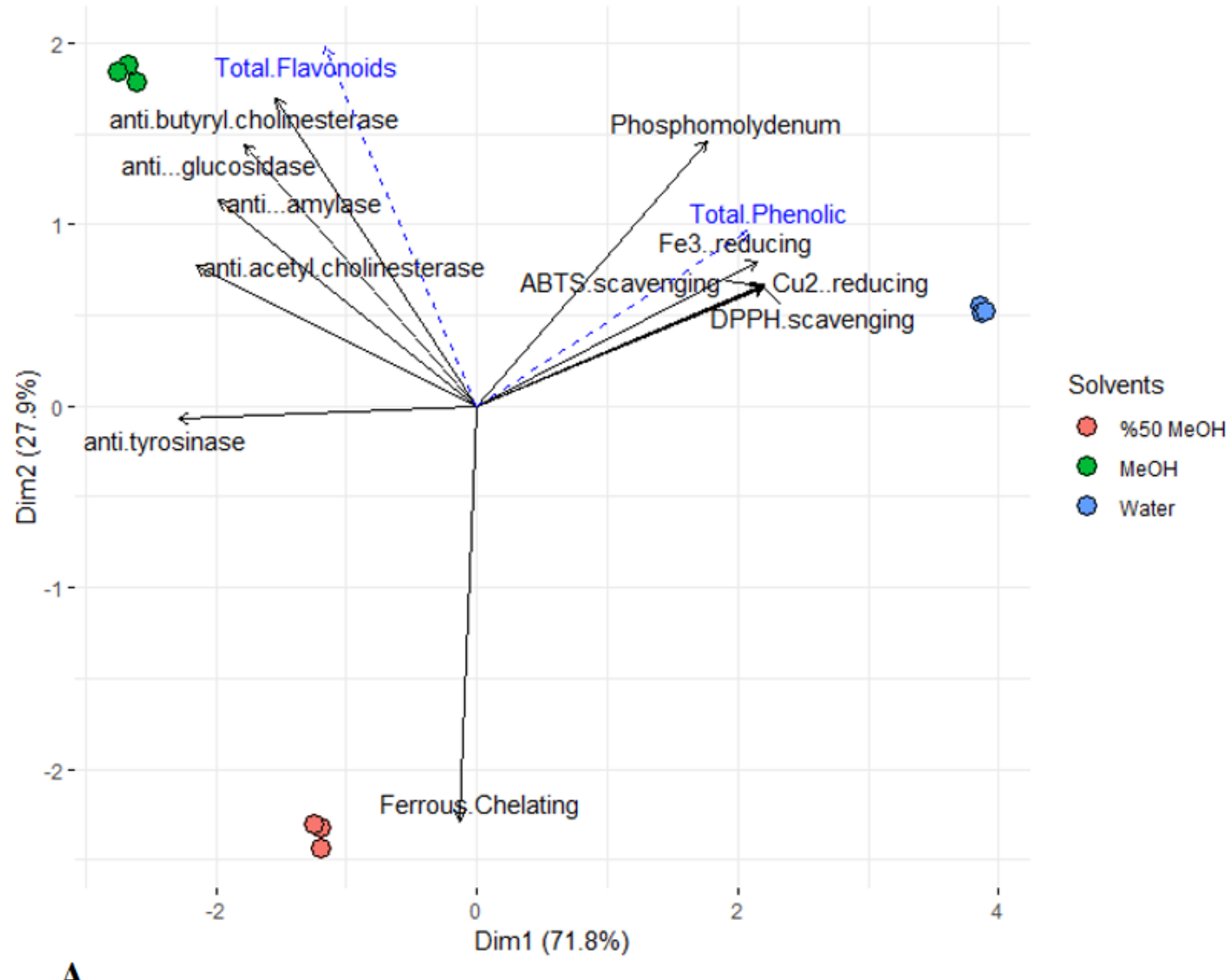

Contribution of variables to Dim-1

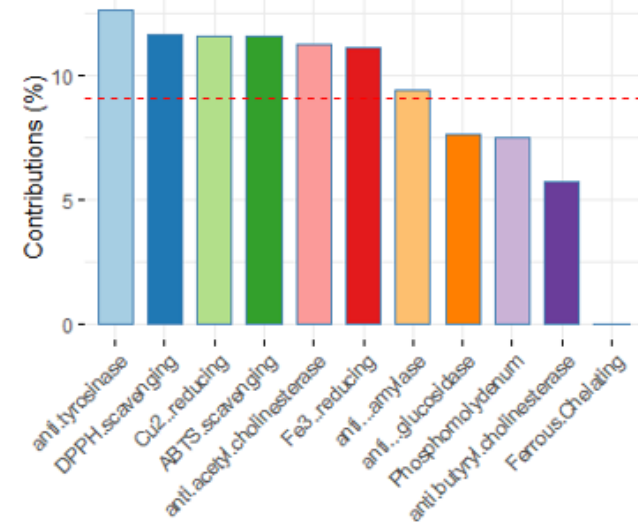

Contribution of variables to Dim-2

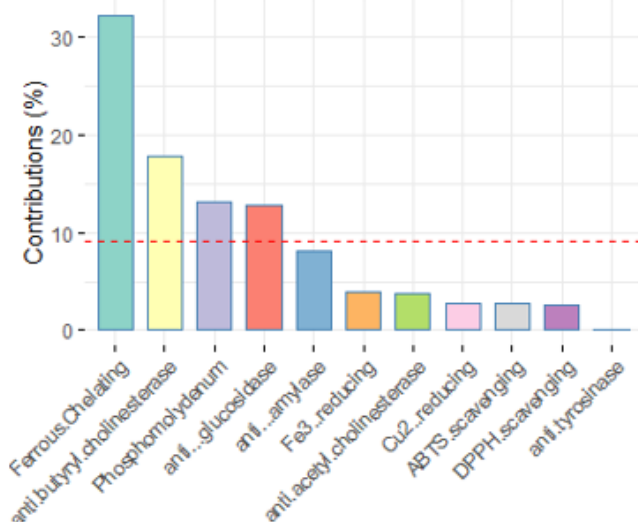

Figure 1. Exploratory multivariate analysis principal component analysis on biological activities of Prunus avium. A: Biplot representing samples and biological activities in the space PC1 vs PC2. B: Relation between the 11 biological activities and the principal component 
Polyphenols derived from plants are known to be effective antioxidants and thus play significant role in many disease prevention. Therefore, in order to estimate the antioxidant capacity of $P$. avium extracts, a plethora of complementary antioxidant assays including DPPH, ABTS, FRAP, CUPRAC, phosphomolybdenum and metal chelating activity were conducted. The antioxidant capacity varied among the solvents. The free radical scavenging activity of studied extracts was assessed by DPPH and ABTS. Highest effect on DPPH and ABTS was shown by $P$. avium-water extract. Recent research reported that DPPH activity of $P$. avium (leaves, flowers and stem extracts) was determined in the range of $\mathrm{IC}_{50}: 22.37 \mu \mathrm{g} / \mathrm{ml}-61.59 \mu \mathrm{g} / \mathrm{ml}$ (Jesus, Gonçalves, Alves \& Silva, 2019). Our results revealed that $P$. avium water extract had a better CUPRAC and FRAP activity than $P$. avium-MeOH and $P$. avium- $50 \% \mathrm{MeOH}$.

The total antioxidant capacity of $P$. avium extracts was evaluated through phosphomolybdenum assay. As shown in Table 2, the total antioxidant capacity varied between 1.39 and $2.33 \mathrm{mmol} \mathrm{TE} / \mathrm{g}$. In metal chelating assay, $P$. avium- $50 \% \mathrm{MeOH}$ had highest activity (60.16 mg EDTAE/g), followed by $P$. avium-water extract (34.89 $\mathrm{mg}$ EDTAEs $/ \mathrm{g}$ ) and $P$. avium-MeOH extract (26.09 mg EDTAE/g). From these results, the antioxidant capacity may be related to the presence phenolic compounds. This finding is consistent with the observation by (Acero et al., 2019) who reported the highest antioxidant capacity of three Spanish variates of $P$. avium is related to presence of phenolic compounds. Another study conducted by Kelebek \& Selli (2011) indicated that antioxidant properties of sweet cherry cultivars grown in Turkey can be correlated to the presence of phenolic compounds. Based on our results, water was found to be the most suitable solvent for extracting phenolic compounds responsible for the observed antioxidant activities of $P$. avium leaves.

Table 2. Antioxidant capacity of Prunus avium leaves

\begin{tabular}{lccc}
\hline Assays & Prunus avium-MeOH & Prunus avium-50\% MeOH & Prunus avium-Water \\
\hline $\begin{array}{l}\text { DPPH assay } \\
\text { (mg TE/g extract) }\end{array}$ & $96.63 \pm 0.22^{\mathrm{b}^{*}}$ & $82.85 \pm 1.53^{\mathrm{c}}$ & $252.47 \pm 7.23^{\mathrm{a}}$ \\
\hline $\begin{array}{l}\text { ABTS assay } \\
\text { (mg TE/g extract) }\end{array}$ & $116.43 \pm 2.85^{\mathrm{b}}$ & $103.49 \pm 2.11^{\mathrm{c}}$ & $251.12 \pm 5.42^{\mathrm{a}}$ \\
\hline $\begin{array}{l}\text { CUPRAC assay } \\
\text { (mg TE/g extract) }\end{array}$ & $202.41 \pm 8.49^{\mathrm{b}}$ & $180.07 \pm 3.14^{\mathrm{c}}$ & $457.42 \pm 4.15^{\mathrm{a}}$ \\
\hline $\begin{array}{l}\text { FRAP assay } \\
\text { (mg TE/g extract) }\end{array}$ & $119.22 \pm 2.38^{\mathrm{b}}$ & $96.27 \pm 2.48^{\mathrm{c}}$ & $248.27 \pm 5.70^{\mathrm{a}}$ \\
\hline $\begin{array}{l}\text { Phosphomolybdenum } \\
\text { (mmol TE/g extract) }\end{array}$ & $1.82 \pm 0.04^{\mathrm{b}}$ & $1.39 \pm 0.03^{\mathrm{c}}$ & $2.33 \pm 0.04^{\mathrm{a}}$ \\
\hline $\begin{array}{l}\text { Metal chelating activity } \\
\text { (mg EDTAE/g extract) }\end{array}$ & $26.09 \pm 0.79^{\mathrm{c}}$ & $60.16 \pm 1.69^{\mathrm{a}}$ & $34.89 \pm 1.42^{\mathrm{b}}$ \\
\hline
\end{tabular}

${ }^{*}$ Values expressed are means \pm SD. TE, trolox equivalents, EDTAE, disodium edetate equivalents, Different superscripts indicate significant differences in the extracts $(p<0.05)$. 
The enzyme inhibitory effect of $P$. avium extracts was investigated against AChE, BChE, $\alpha$-amylase, $\alpha$-glucosidase and tyrosinase. The antidiabetic activity was assessed by two in vitro assays ( $\alpha$-amylase, $\alpha$-glucosidase). The $P$. avium-MeOH extract showed higher antidiabetic activity than other extract. The dermatoprotective activity of extracts was determined by in vitro tyrosinase inhibition assay. The results showed that $P$. avium-MeOH $(136.96 \mathrm{mg}$ $\mathrm{KAE} / \mathrm{g}$ ), followed by $P$. avium $-50 \% \mathrm{MeOH}$, while that of water extract was the least
(32.52 $\mathrm{mg} \mathrm{KAE} / \mathrm{g}$ ). As for cholinesterase inhibition (AChE and $\mathrm{BChE}$ ), P. aviumwater extract showed no anti-cholinesterase activity. As shown in Table 3, only the $P$. avium-MeOH extract displayed inhibitory effect against $\mathrm{BChE}$ enzyme. According to the literature, the knowledge about enzyme inhibitory effect on $P$. avium leaves is still very limited. There are only a few studies. In an earlier report, the $\alpha$-glucosidase activity of $P$. avium was higher in stem extract compared with leaves and flowers extract (Jesus et al., 2019).

Table 3. Enzyme inhibitory effect of Prunus avium leaves

\begin{tabular}{lccc}
\hline Assays & Prunus avium-MeOH & Prunus avium-50\% MeOH & Prunus avium-Water \\
\hline $\begin{array}{l}\text { Acetylcholinesterase } \\
\text { (mg GALAE/g extract) }\end{array}$ & $4.60 \pm 0.08^{* \mathrm{a}}$ & $2.16 \pm 0.12^{\mathrm{b}}$ & nd \\
\hline $\begin{array}{l}\text { Butyrylcholinesterase } \\
\text { (mg GALAE/g extract) }\end{array}$ & $2.48 \pm 0.07^{\mathrm{a}}$ & $\mathrm{nd}$ & $\mathrm{nd}$ \\
\hline $\begin{array}{l}\alpha-\text { Amylase inhibition } \\
\text { (mmol ACE/g extract) }\end{array}$ & $0.53 \pm 0.03^{\mathrm{a}}$ & $0.24 \pm 0.03^{\mathrm{b}}$ & $0.10 \pm 0.01^{\mathrm{c}}$ \\
\hline $\begin{array}{l}\alpha-\text { Glucosidase inhibition } \\
\text { (mmol ACE/g extract) }\end{array}$ & $25.18 \pm 0.01^{\mathrm{a}}$ & $8.37 \pm 0.58^{\mathrm{b}}$ & $5.10 \pm 0.07^{\mathrm{c}}$ \\
\hline $\begin{array}{l}\text { Tyrosinase inhibition } \\
\text { (mg KAE/g extract) }\end{array}$ & $136.96 \pm 0.20^{\mathrm{a}}$ & $116.84 \pm 0.78^{\mathrm{b}}$ & $32.52 \pm 4.64^{\mathrm{c}}$ \\
\hline $\begin{array}{l}{ }^{*} \text { Values expressed are means } \pm \text { SD. GALAE, galanthamine equivalents; ACE, acarbose equivalents; KAE, kojic acid } \\
\text { equivalents; nd: not determined. Different superscripts indicate significant differences in the extracts }(p<0.05) .\end{array}$
\end{tabular}

\section{Conclusion}

This is the first extensive report of in vitro antioxidant capacity and enzyme inhibitory effect of $P$. avium leaves. Our results revealed that the water extract of $P$. avium leaves displayed strong antioxidant activity. For enzyme inhibition, methanol was the most effective solvents. Overall, $P$. avium leaves could be a potential candidate for development as a new natural antioxidant and inhibitory agents.

\section{References}

Acero, N., Gradillas, A., Beltran, M., García, A. \& Mingarro, D.M. (2019). Comparison of phenolic compounds profile and antioxidant properties of different sweet cherry (Prunus avium L.) varieties. Food Chemistry, 279, 260-271.

Asghari, B., Mafakheri, S., Zarrabi, M.M., Erdem, S. A., Orhan, I.E., \& Bahadori, M.B. (2019). Therapeutic target enzymes inhibitory potential, antioxidant activity, and rosmarinic acid content of Echium amoenum. South African Journal of Botany, 120, 191-197.
Azwanida, N. N. (2015). A review on the extraction methods use in medicinal plants, principle, strength and limitation. Medicinal \& Aromatic Plants, 4(196), 2167-0412.

Bahadori, M.B., Zengin, G., Bahadori, S., Dinparast, L., \& Movahhedin, N. (2018). Phenolic composition and functional properties of wild mint (Mentha longifolia var. calliantha (Stapf) Briq.). International Journal of Food Properties, 21(1), 183-193.

Banerjee, J., Singh, R., Vijayaraghavan, R., MacFarlane, D., Patti, A.F. \& Arora, A. (2017). Bioactives from fruit processing wastes: Green approaches to valuable chemicals. Food Chemistry, 225, 10-22.

Chai, W.M., Huang, Q., Lin, M.Z., Ou-Yang, C., Huang, W.Y., Wang, Y.X., Xu, K.L. \& Feng, H.L. (2018). Condensed tannins from longan bark as inhibitor of tyrosinase: structure, activity, and mechanism. Journal of Agricultural and Food Chemistry, 66(4), 908917.

Dziadek, K., Kopeć, A. \& Tabaszewska, M. (2019). Potential of sweet cherry (Prunus avium L.) by-products: Bioactive compounds and antioxidant activity of leaves and petioles. 
European Food Research and Technology, 245, 763-772.

Dziadek, K., Kopeć, A. \& Czaplicki, S. (2018). The petioles and leaves of sweet cherry (Prunus avium L.) as a potential source of natural bioactive compounds. European Food Research and Technology, 244(8), 14151426.

Gonçalves, B., Landbo, A.K., Knudsen, D., Silva, A.P., Moutinho-Pereira, J., Rosa, E. \& Meyer, A.S. (2004). Effect of ripeness and postharvest storage on the phenolic profiles of cherries (Prunus avium L.). Journal of Agricultural and Food Chemistry, 52(3), 523530.

Grochowski, D.M., Uysal, S., Zengin, G. \& Tomczyk, M. (2019). In vitro antioxidant and enzyme inhibitory properties of Rubus caesius L. International Journal of Environmental Health Research, 29(3), 237-245.

Jesus, F., Gonçalves, A.C., Alves, G. \& Silva, L.R. (2019). Exploring the phenolic profile, antioxidant, antidiabetic and anti-hemolytic potential of Prunus avium vegetal parts. Food Research International, 116, 600-610.

Kelebek, H. \& Selli, S. (2011). Evaluation of chemical constituents and antioxidant activity of sweet cherry (Prunus avium L.) cultivars. International Journal of Food Science \& Technology, 46(12), 2530-2537.

Kent, K., Charlton, K.E., Jenner, A. \& Roodenrys, S. (2016). Acute reduction in blood pressure following consumption of anthocyanin-rich cherry juice may be doseinterval dependant: a pilot cross-over study. International Journal of Food Sciences and Nutrition, 67(1), 47-52.

Li, H. Y., Hao, Z. B., Wang, X. L., Huang, L. \& Li, J.P. (2009). Antioxidant activities of extracts and fractions from Lysimachia foenum-graecum Hance. Bioresource Technology, 100(2), 970-974.

Masondo, N. A., Stafford, G. I., Aremu, A.O. \& Makunga, N.P. (2019). Acetylcholinesterase inhibitors from southern African plants: An overview of ethnobotanical, pharmacological potential and phytochemical research including and beyond Alzheimer's disease treatment. South African Journal of Botany, 120, 39-64.

McCune, L.M., Kubota, C., Stendell-Hollis, N.R. \& Thomson, C.A. (2010). Cherries and health: a review. Critical Reviews in Food Science and Nutrition, 51(1), 1-12.

Mollica, A., Zengin, G., Durdagi, S., Ekhteiari Salmas, R., Macedonio, G., Stefanucci, A., Dimmito, M.P. \& Novellino, E. (2019). Combinatorial peptide library screening for discovery of diverse $\alpha$-glucosidase inhibitors using molecular dynamics simulations and binary QSAR models. Journal of Biomolecular Structure and Dynamics, 37(3), 726-740.

Mollica, A., Zengin, G., Stefanucci, A., Ferrante, C., Menghini, L., Orlando, G., Brunetti, L., Locatelli, M., Dimmito, M.P., Novellino, E., Wakeel, O.K., Ogundeji, M.O., Onaolapo, A.Y. \& Onaolapo, O.J. (2018). Nutraceutical potential of Corylus avellana daily supplements for obesity and related dysmetabolism. Journal of Functional Foods, 47, 562-574.

Murayyan, A.I., Manohar, C.M., Hayward, G. \& Neethirajan, S. (2017). Antiproliferative activity of Ontario grown onions against colorectal adenocarcinoma cells. Food Research International, 96, 12-18.

Nawirska-Olszańska, A., Kolniak-Ostek, J., Oziembłowski, M., Ticha, A., Hyšpler, R., Zadak, Z., Zidova, P. \& Paprstein, F. (2017). Comparison of old cherry cultivars grown in Czech Republic by chemical composition and bioactive compounds. Food Chemistry, 228(1), 136-142.

Rauf, A. \& Jehan, N. (2017). Natural products as a potential enzyme inhibitors from medicinal plants. In Enzyme Inhibitors and Activators, 165-177.

Scalbert, A., Johnson, I.T. \& Saltmarsh, M. (2005). Polyphenols: antioxidants and beyond. The American Journal of Clinical Nutrition, 81(1), 215-217.

Serradilla, M.J., Martín, A., Ruiz-Moyano, S., Hernández, A., López-Corrales, M. \& de Guía Córdoba, M. (2012). Physicochemical and sensorial characterisation of four sweet cherry cultivars grown in Jerte Valley (Spain). Food Chemistry, 133(4), 1551-1559.

Średnicka-Tober, D., Ponder, A., Hallmann, E., Głowacka, A. \& Rozpara, E. (2019). The profile and content of polyphenols and carotenoids in local and commercial sweet cherry fruits (Prunus avium L.) and their antioxidant activity in vitro. Antioxidants, 8(11), 534.

Usenik, V., Fabčič, J. \& Štampar, F. (2008). Sugars, organic acids, phenolic composition and antioxidant activity of sweet cherry (Prunus avium L.). Food Chemistry, 107(1), 185-192.

Uysal, A., Ozer, O.Y., Zengin, G., Stefanucci, A., Mollica, A., Picot-Allain, C. M. N. \& Mahomoodally, M. F. (2019). Multifunctional approaches to provide potential pharmacophores for the pharmacy shelf: Heracleum sphondylium L. subsp. ternatum 
(Velen.) Brummitt. Computational Biology and Chemistry, 78, 64-73.

Uysal, S., Zengin, G., Locatelli, M., Bahadori, M. B., Mocan, A., Bellagamba, G., De Luca, E., Mollica, A. \& Aktumsek, A. (2017). Cytotoxic and enzyme inhibitory potential of two Potentilla species (P. speciosa L. and $P$. reptans Willd.) and their chemical composition. Frontiers in Pharmacology, 8, 290.

Uysal, S. \& Aktumsek, A. (2015). A phytochemical study on Potentilla anatolica: an endemic Turkish plant. Industrial Crops and Products, 76, 1001-1007.

Wu, T., Tang, Q., Yu, Z., Gao, Z., Hu, H., Chen, W., Zheng, X. \& Yu, T. (2014). Inhibitory effects of sweet cherry anthocyanins on the obesity development in C57BL/6 mice. International Journal of Food Sciences and Nutrition, 65(3), 351-359.

Zengin, G., Stefanucci, A., Rodrigues, M.J., Mollica, A., Custodio, L., Aumeeruddy, M.Z., \& Mahomoodally, M. F. (2019). Scrophularia lucida L. as a valuable source of bioactive compounds for pharmaceutical applications: in vitro antioxidant, anti-inflammatory, enzyme inhibitory properties, in silico studies, and HPLC profiles. Journal of Pharmaceutical and Biomedical Analysis, 162, 225-233. 